\title{
The trade impacts of China's Belt and Road Initiative: from resource and environmental perspectives
}

\author{
Xu Tian ${ }^{1,2}$, Yunyi $\mathrm{Hu}^{3}$, Haitao Yin $^{3 *}$, Yong Geng ${ }^{1,4,5^{*}}$, Raimund Bleischwitz $2^{2 *}$
}

1 School of Environmental Science and Engineering, Shanghai Jiao Tong University, Shanghai 200240, China

2 Institute for Sustainable Resources, Bartlett School of Environment, Energy and Resources, University College London, Central House, 14 Upper Woburn Place, London WC1H 0NN, United Kingdom

3 Antai College of Economics \& Management, Shanghai Jiao Tong University, Shanghai 200030, China

4 China Institute of Urban Governance, Shanghai Jiao Tong University, Shanghai 200240, China

5 Shanghai Institute of Pollution Control and Ecological Security, Shanghai 200092, China

*Corresponding author:

ygeng@sjtu.edu.cn Telephone: +86-21-54748019, Fax: +86-21-54740825

htyin@sjtu.edu.cn Telephone: +86-21-52301242

r.bleischwitz@ucl.ac.uk

\section{Abstract:}

China's 'Belt and Road Initiative' (BRI) is a major global initiative with severe implications for economies, policies and societies; yet its impacts on environment and natural resource use have received little attention. This paper fills such a gap by assessing environmental and resource impacts of China's international trade with those BRI countries after the start of the BRI in 2013. Despite potential concerns over problem shifting, we find that China's net export growth after the BRI is concentrated in pollution-intensive and resource-intensive industries, compared to what would happen otherwise, and therefore increases China's domestic environmental and resource burden. This alleviates the concern over a migration of pollution and resource exploitation from China to other BRI countries and provides valuable insights to the Chinese policy makers. Several policy recommendations are raised in order to improve the overall sustainability of China's BRI. 
Keywords: The Belt and Road Initiative; trade; environment; resource; governance

\section{Introduction}

Environmental and resource impacts of globalization have been concerns for scholars and practitioners in the field of international economics, environmental and resource protection, and international politics (Grossman and Krueger, 1994; Lin et al., 2014). As China's environmental regulations become more stringent and its capital outflow gains prominence, concern arises that China's international trade and investment may lead to another round of shifting pollution and resource exploration to the less developed world. This concern would undoubtedly plague regional integration and international economic cooperation which China aspires to.

China's One Belt and One Road Initiative (BRI), including the Silk Road Economic Belt and the $21^{\text {st }}$ Century Maritime Silk Road, is China's key national strategy of strengthening its economic integration with Asia, and parts of Europe and Africa, building up a new future-oriented consensus for international cooperation. Trade is one of the core fields in the BRI. The BRI has received high attention internationally and the main achievements on trade promotion after China's BRI have been remarkable since $2013^{1}$. While, as many previous trade studies claimed, trade could result in resources and environmentally detrimental balances and trade shifts in terms of flows embodied in traded commodities (Tian et al., 2018), global issues such as "carbon leakage" and "ecologically unequal exchange" occurred across nations with different levels of economic development, resulting in greater overall environmental and natural resources degradation (Bruckner et al., 2012; Dalin et al., 2012; Peters et al., 2011). Since many countries along the BRI have a GDP per capital lower than the world average (Liu et al., 2018) and are economically less developed than China, concerns exist that the BRI would shift China's environmental and resource woes to these countries. Therefore, it is urgent to reveal the corresponding resource and environmental impacts of the BRI policy.

\footnotetext{
${ }^{1}$ https://eng.yidaiyilu.gov.cn/.
} 
Our article goes beyond existing knowledge, which has been mainly on economic benefits due to infrastructure investments (Fan, 2018), Chinese overseas direct investment (Du and Zhang, 2018), the CNY's position in the BRI countries' foreign currency network (Li et al., 2018), and overseas energy investment (Duan et al., 2018); other papers have looked at the potential impacts on carbon emissions (Liu and Hao, 2018; Zhang et al., 2017), virtual water (Zhang et al., 2018), China's competitiveness in PV products (Shuai et al., 2018), global health (Hu et al., 2017), and mineral resources (Liu et al., 2018). In particular, just a few studies discussed the resources and environmental issues associated with the BRI (Cai et al., 2018; Liu et al., 2018; Liu and Hao, 2018; Zhang et al., 2017; Zhang et al., 2018). These studies are either product specific (Zhang et al., 2018), or pollutant specific (Liu and Hao, 2018). Most importantly, they do not consider controlling the BAU (Business-As-Usual) scenarios, and therefore only describe a snapshot of the environmental and resource exchanges through trade between China and the BRI countries.

Our study distinguishes itself from the existing literatures in the following two aspects. First, we employ a Difference-in-Difference (DID) method which has been applied to evaluate impacts via the two differences in outcomes (Abadie, 2005; Donald and Lang, 2007; Jian et al., 2015; Slaughter, 1998) to estimate whether and how the BRI has changed China's trade pattern with the BRI countries, using non-BRI countries as a benchmark. The DID method allows to discuss environmental and resource impacts resulting from the BRI, instead of providing a static description. Second, we use data from China's statistical customs yearbooks for the period of 2008-2016, covering all manufacturing industries and all products. An industry-by-industry analysis reveals the industrial sectors that have experienced significant changes in both import and export. Linking this finding with a pollution and resource analysis of different sectors, we identify potential environmental and resources impacts of the BRI through reshaping trade patterns between China and other BRI countries. This study helps quantifying environmental and resources impacts of the BRI, facilitates the integration of environmental and resource concerns into the current BRI blueprint, and enables transitions to a more sustainable BRI. 
The rest of the paper runs as follows. Section 2 introduces our method and data. Section 3 presents the key findings. Section 4 and section 5 conclude the paper with a discussion of policy implications.

\section{Methods and Data Sources}

\subsection{Difference-in-Differences setting (DID)}

In this study, we apply DID regressions to compare the changes of China's trade with the BRI countries (The original countries along BRI in this study are shown in Figure 1) after the BRI to that with the non-BRI countries. The advantage of DID method is that it can help analyze the different outcomes and has been widely applied for policy evaluation. Outcomes after and before the policy are compared between groups with and without the exposure, which allows subtracting the background changes in outcomes and an impact assessment of the policy implementation (Abadie, 2005; Donald and Lang, 2007; Jian et al., 2015; Slaughter, 1998). Despite the apparent differences between BRI and non-BRI countries in terms of geographical locations and institutions, non-BRI countries can serve as a good benchmark for the globe trade trend because of the absence of similar policy shock to non-BRI countries ${ }^{2}$.

We divide all countries into two groups, namely treatment group (BRI countries) and control group (non-BRI countries). As the BRI was first announced by President Xi Jinping in Kazakhstan in 2013, we treat 2014 and 2016 as the post-policy years, and 2008, 2010 and 2012 as the pre-policy years. Equation (1) shows the DID regression:

trade $_{i, j, t}=\alpha_{j, t}+\beta_{1, j} \cdot B R_{i}+\beta_{2, j} \cdot$ policy $_{t}+\beta_{3, j} \cdot B R_{i} \cdot$ policy $_{t}+\beta_{d, j} \cdot$ Dist $_{i}+$ $\beta_{p, j} \cdot \operatorname{Pop}_{i, t}+\beta_{g, j} \cdot G D P_{i, t}+\theta_{j, t}+\delta_{i, j}+\varepsilon_{i, j, t}$

Where the dependent variable $\operatorname{trade}_{i, j, t}$ is the trade volume in industrial sector $j$ between China and country $i$ in year $t$. We use the volumes of export, import and total trade in different specifications, industrial sectors, as well as on the entire industry as a whole. On the right-hand side, $B R_{i, j}$ is a dummy variable, which equals to 1 if

\footnotetext{
2 We test the pretreatment parallel consumption by regressing the following specification (2). The results suggest a common trend of trade between BR and non-BR countries before the BRI.

trade $_{i, j, t}=\alpha_{j, t}+\beta_{1, j} \cdot B R_{i}+\sum_{u=2008}^{2016} \beta_{2, j, u} \cdot$ year $_{u}+B R_{i} \cdot \sum_{u=2008}^{2016} \beta_{2, j, u} \cdot$ year $_{u}+\beta_{d, j} \cdot$ Dist $_{i}+\beta_{p, j} \cdot$ Pop $_{i, t}+\beta_{g, j} \cdot G D P_{i, t}+\theta_{j, t}+\delta_{i, j}+\varepsilon_{i, j, t}(2)$ 
country $i$ is one BRI country and 0 otherwise; the variable of policy,t $y_{j}$ indicates the post-treatment period, which equals to 1 when it is after the year of 2014 . The coefficient $\beta_{2, j}$ measures the trade volume changes of non-BRI countries after BRI policy; The coefficient $\beta_{2, j}+\beta_{3, j}$ measure the trade volume changes of BRI countries after BRI policy; therefore, we concentrate on the coefficient $\beta_{3, j}$ which presents the impacts of BRI policy on BRI countries. We follow a gravity model of trade to control for several country-level variables (Chen, 2018). We use the distance between the capital of one country and Beijing to measure the corresponding transportation cost. GDP and population influence one country's demand on international trade. Year fixed effect is included to capture all yearly factors common to all countries such as macroeconomic shock. Country fixed effect is also included to control for non-observable country-specific characteristics that are constant over the time.

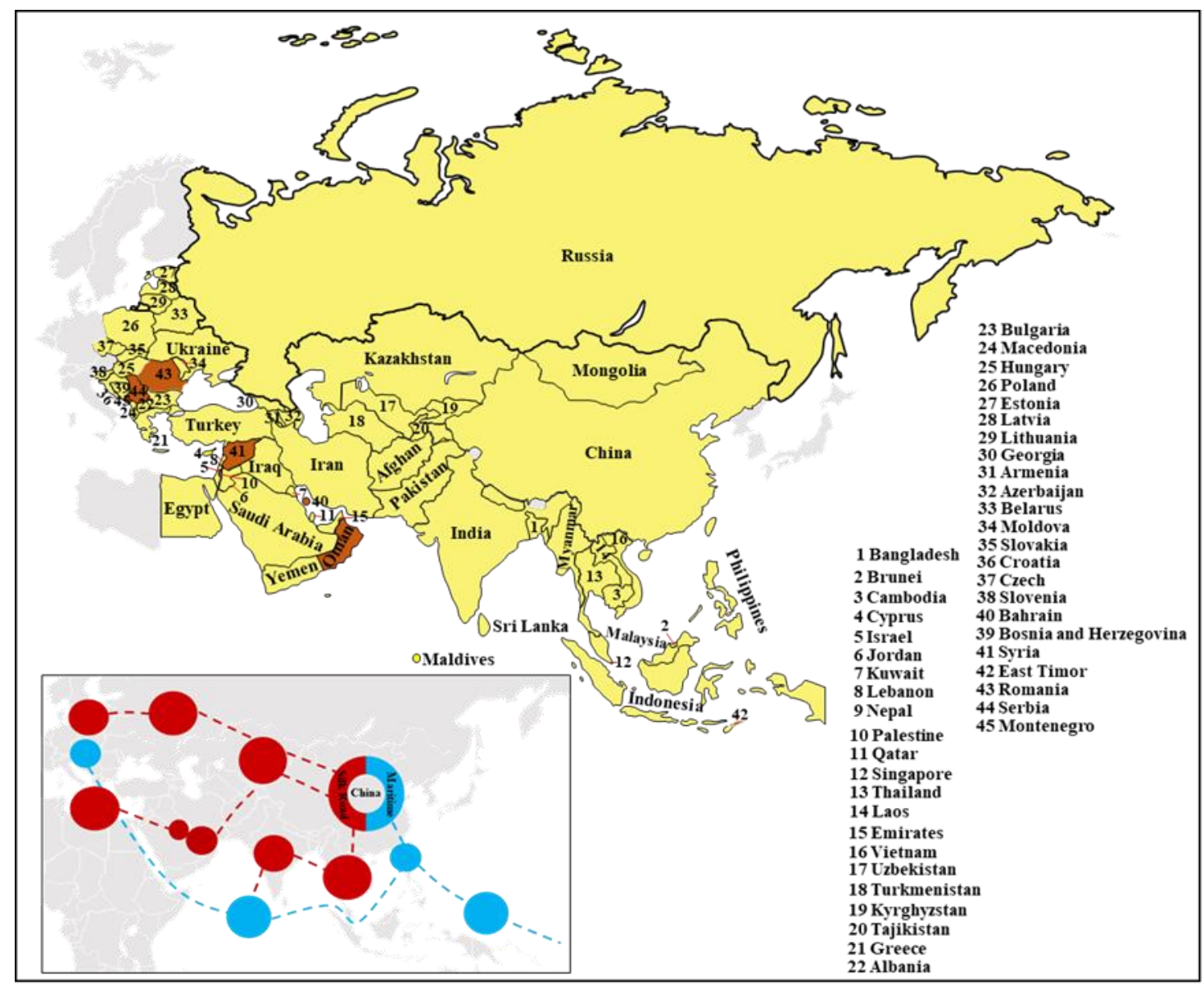


Figure 1 Countries along China's BRI (Note: the red line in the picture is China's Silk Road, and the blue line is the Maritime Silk Road. The countries in yellow color are investigated in this study)

\subsection{Data}

In this study, China's Customs Statistical Yearbooks for years 2008, 2010, 2012, 2014 and 2016 are used as the main data sources (CCSY, 2008-2016). In addition, we utilize the Centre for Prospective Studies and International Information (CEPII) database, the World Bank database, China Stock Market \& Accounting Research (CSMAR) Database, China's Statistical Yearbook 2014 and China’s Environment Statistical Yearbook 2014.

Each China's Customs Statistical Yearbook provides the volumes that China exports to and imports from all countries based on HS code with 6 digits. We aggregate them to the industry level based on the 2-digit Standard International Trade Classification (SITC) ${ }^{3}$. Compared with the primary industry and the tertiary industry, due to the relatively large environmental impact of manufacturing industry, our study only considers 27 typical manufacturing industrial sectors. Since the trade volume is measured at the value of current year, we eliminate the impact of price fluctuation via dividing trade value by consumer price index ${ }^{4}$. As a result, all values in this analysis are at the 2010 price.

The list of BRI countries is collected from the Belt and Road Portal (Bringezu et al., 2004). This website presents comprehensive information on BRI, helping compile the 65 countries along BRI (see Figure 1) (due to the data availability, in this study we only run results from 58 major BRI countries). We use four environmental and resource indicators: air pollution, $\mathrm{CO}_{2}$ emission, water consumption and energy consumption. Air pollution is an aggregate indicator considering $\mathrm{PM}, \mathrm{NOx}, \mathrm{SO}_{2}, \mathrm{NH}_{3}, \mathrm{VOC}$ and $\mathrm{CO}$ emission. We compile pollution intensity (which equals to total pollution emission of each sector divided by total output of this sector) and resource intensity (which equals to total resource consumption of each sector divided by total output of this sector) at industrial level from Eora database (http://www.worldmrio.com/). We obtain

\footnotetext{
${ }^{3}$ http://114.xixik.com/hangyefenlei/.

4 The trade volume is in 2010 constant US dollars. Annual consumer price index is from CSMAR.
} 
population and GDP data from the World Bank database and the distance variables from the CEPII database. Our primary sample contains 211 countries, 65 BRI countries and 146 non-BRI countries. We exclude those countries with missing values of distance, population or GDP. Finally, 174 countries (58 BRI countries and 116 non-BRI countries) are included in this study.

\section{Results}

3.1 The impacts of BRI on China's international trade

First, we look at how the BRI has affected the trade between China and the BRI countries before and after the BRI policy. Table 1 presents the estimated results. In column (1) and (3), coefficients of $B R$ are significantly negative, indicating that before starting the BRI, both total exports and net exports with the BRI countries are lower than those with the non-BRI countries. The positive coefficient of Policy in column (1) shows that after the year 2014, China's export volume with all countries increased. With respect to the total import, the coefficient of $B R$ is significantly positive, indicating that China imported more from the BRI countries than the non-BRI countries before the policy. The positive Policy suggests that after BRI, China has imported more from both the BRI and non-BRI countries. In all columns, the coefficients for the interaction term between $B R$ \& Policy are insignificant, indicating that after the BRI, the trade with the BRI countries does not differ from the non-BRI countries at the aggregate level.

Table 1 The Impacts of BRI on China's International Trade: An Aggregate View

\begin{tabular}{|c|c|c|c|}
\hline Dependent Variables (Billion USD) & $\begin{array}{c}\text { (1) } \\
\text { Total Export }\end{array}$ & $\begin{array}{c}\text { (2) } \\
\text { Total Import }\end{array}$ & $\begin{array}{c}\text { (3) } \\
\text { Net Export }\end{array}$ \\
\hline $\mathrm{BR}$ & $\begin{array}{l}-4.116 * * \\
(1.874)\end{array}$ & $\begin{array}{l}3.120 * * * \\
(1.190)\end{array}$ & $\begin{array}{l}-7.236 * * * \\
(1.290)\end{array}$ \\
\hline Policy & $\begin{array}{l}1.226 * \\
(0.664)\end{array}$ & $\begin{array}{l}1.395 * * * \\
(0.489)\end{array}$ & $\begin{array}{l}-0.169 \\
(0.721)\end{array}$ \\
\hline BR \&Policy & $\begin{array}{l}0.397 \\
(0.758)\end{array}$ & $\begin{array}{l}-0.331 \\
(0.500)\end{array}$ & $\begin{array}{l}0.728 \\
(0.696)\end{array}$ \\
\hline GDP (10 12 USD) & $\begin{array}{l}7.058 \\
(6.003)\end{array}$ & $\begin{array}{l}4.390 * \\
(2.667)\end{array}$ & $\begin{array}{l}2.669 \\
(3.544)\end{array}$ \\
\hline Population (Million) & $\begin{array}{l}0.13 * * \\
(0.54)\end{array}$ & $\begin{array}{l}-0.10 * * * \\
(0.32)\end{array}$ & $\begin{array}{l}0.23 * * * \\
(0.36)\end{array}$ \\
\hline
\end{tabular}




\begin{tabular}{llll} 
Distance (Thousand km) & $0.707^{* *}$ & 0.009 & $0.698^{* * *}$ \\
& $(0.360)$ & $(0.266)$ & $(0.249)$ \\
Year FE & Included & Included & Included \\
Country FE & Included & Included & Included \\
Constant & $-4.236^{* *}$ & -1.554 & $-2.682^{* *}$ \\
Observations & $(1.901)$ & $(1.485)$ & $(1.175)$ \\
R-squared & 870 & 870 & 870 \\
\hline
\end{tabular}

Note: All tests are two-detailed. Robust standard errors are in the parentheses. ${ }^{*} p<0.10,{ }^{* *} p<0.05$, $* * * p<0.01$.

The analysis at an aggregate level may mask structural shifts: trade may increase in some sectors while decrease in other sectors. But this structural shift should offer more insights on environmental and resource impacts of international trade because the intensity of pollution and resource consumption varies significantly across different industrial sectors.

In order to look at the possible changes in trade compositions, we run the regression analyses (1) at the level of different industrial sectors, and separately for export, import and net export. For conciseness, Table 2 only reports the coefficients of BRI Policy from these 27 industry-specific regressions. These coefficients capture how the BRI has changed the trade volume in each industrial sector, compared to what would have happened without the BRI. As shown in Table 2, there is considerable heterogeneity in the impacts of the BRI on export, import and net export across different industrial sectors.

Table 2 BRI's impact on import, export and net export across different industrial sectors

\begin{tabular}{llcl}
\hline Industry & \multicolumn{1}{c}{$(1)$} & $(2)$ & $(3)$ \\
& Export & Import & Net Export \\
\hline Mining & $0.005^{*}$ & 0.017 & -0.013 \\
Wine and Drinks & 0.000 & $-0.011 * *$ & $0.011^{*}$ \\
Textile industry & $0.197 * * *$ & $0.045^{* * *}$ & $0.152^{* * *}$ \\
Leather, Fur, Feather and Related Products & 0.044 & 0.014 & 0.030 \\
Paper and Paper Products & $0.029 * * *$ & -0.005 & $0.034 * * *$ \\
Fuel processing & $0.101 * * *$ & 0.147 & -0.047 \\
Chemical Materials and Products & $0.053 *$ & 0.093 & -0.040 \\
Pharmaceuticals & 0.002 & $-0.090 * * *$ & $0.092 * * *$ \\
Rubber and Plastic & 0.001 & -0.002 & 0.003
\end{tabular}


Non-metallic Mineral Products

Smelting of Ferrous Metals

Smelting of Non-ferrous Metals

Metal Products

Agro-food processing industry

Foods

Tobacco

Timber, Wood, Bamboo, Rattan, Palm, and Straw

Products

Textile Wearing and Apparel

Printing, Reproduction of Recording Media

Articles for Culture, Education and Sport Activity

General Purpose Machinery

Special Purpose Machinery

Automobile

Other Transportation Equipment

Electrical Machinery and Equipment

Other Electronic Equipment

Measuring Instrument

$\begin{array}{lll}0.044 * & -0.019 * * * & 0.062 * * * \\ 0.159 * * * & 0.001 & 0.157 \\ 0.067 * * * & -0.188 & 0.255^{*} \\ 0.111 * & 0.010 & 0.102 * \\ 0.014 & -0.066 * * & 0.080 * * * \\ 0.000 & -0.036 * * * & 0.037 * * * \\ 0.001 & -0.004 * & 0.005 * \\ -0.006 & -0.004 & -0.002 \\ -0.06 & 0.023 * * * & -0.083 \\ -0.003 * * & 0.003 & -0.006 * \\ -0.124 & 0.003 & -0.127 \\ 0.066 & -0.031 & 0.097 \\ 0.053 * * * & -0.007 & 0.060 * * * \\ -0.037 & -0.210 * * * & 0.173 * * \\ 0.026 & -0.114 * * & 0.140 * * \\ -0.124 & 0.023 & -0.147 \\ -0.206 * & 0.039 & -0.245 * * \\ -0.016 & 0.038 & -0.054\end{array}$

Note: All tests are two-detailed. Robust standard errors are in the parentheses. ${ }^{*} p<0.10, * * p<0.05$, $* * * p<0.01$

When looking at exports, compared to the non-BRI countries, totally 12 industrial sectors show a significant impact on the BRI countries after the implementation of the BRI. Furthermore, 10 industrial sectors show significant increases to the BRI countries. Those fastest growing sectors include textile industry (increased by 197 million USD per year) and smelting of ferrous metals industry (increased by 159 million USD per year). While, the printing, reproduction of recording media industry and other electronic equipment industry present the decreasing trends.

In terms of the BRI impact on imports, compared to the non-BRI countries, 10 industrial sectors experienced significant changes in the BRI countries after the BRI, but only two industrial sectors - textile industry (45 million USD per year) and wearing and apparel industry (23 million USD per year) - increased, compared to the benchmark values (non-BRI countries). The major industries which show significant decreasing trends are automobile industry and other transportation equipment industry.

As for the impact on the net export, we see significant changes in 15 industrial sectors in the BRI countries, compared to the benchmark values. Net exports increased 
in 13 industrial sectors, such as Textile industry and Non-metallic Mineral Products. Other Electronic Equipment industry is the typical one with the decreasing trend.

Although a general trend of changes in BRI countries that would be significantly different from the non-BRI countries after the BRI has not been identified, we discover a diverging pattern across industrial sectors and specific countries. For instance, totally 15 out of 27 industrial sectors in China show significant net exports after implementing the BRI policy, they increased China's net export by 0.6 Billion USD compared to nonBRI countries. Furthermore, summarizing these growing industrial sectors according to the classifications by the Ministry of Ecology and Environment of the People's Republic of China 5 , we find that $54 \%$ of the industrial sectors are pollution-intensive. Therefore, the hypothesis that the BRI would start a new round of pollution migration from China to its BRI partners does not occur.

\subsection{Trade impact on environment and resource consumption}

In order to investigate environmental and resource impacts under BRI, we take China's net export as one example, which is shown in Figure 2. We first calculate the average pollution intensity (pollution per output) in each industry in China. Secondly, we calculate the net export change due to the BRI, compared to what would happen without the BRI, based on the regression analysis in equation (1). Finally, we multiply the net export change by pollution intensity at industrial sector level. Figure 2 shows the results.

It is clear 2 that environmental and resource impacts are mainly concentrated in a few industrial sectors: the smelting of non-ferrous metals industry, smelting of ferrous metals industry, non-metallic mineral products industry, textile industry, pharmaceuticals industry and automobile industry. The net exports increased in these industrial sectors. Aggregating across all industrial sectors, the BRI has led to increasing environmental and resource pressures within China. China's air pollution, $\mathrm{CO}_{2}$ emission, energy consumption and water consumption increased by $11.3 \mathrm{Gg}, 184$ $\mathrm{Gg}, 1.3 \mathrm{PJ}$ and $27 \mathrm{Mm}^{3}$ compared to the BAU scenario.

\footnotetext{
${ }^{5}$ http://www.zhb.gov.cn/gkml/hbb/bgth/200910/t20091022_174891.htm.
} 
Similarly, we can calculate environmental and resource impacts from exports and imports separately. The calculations lead to similar results compared to the analysis of net exports. We find that China's export to the BRI countries has increased after the BRI, particularly in the polluting and resource consuming industrial sectors, compared to the BAU scenario. This again implies that the BRI has resulted in more pollution and resource consumption within the boundary of China, it keeps consistent with Chen (2018), who argues that one of economic drivers for the BRI is to find new markets for the excessive production capacity in China's polluting industrial sectors, and therefore the trade increase would aggregate China's environmental pains (Chen, 2018). At the same time, we find that the imports from the BRI countries did not change significantly, which does not support the view that China is importing more polluting and resourceconsuming products from BRI countries and would therefore fuel up a new round migration of polluting and resource consuming industries from China to the BRI countries. Furthermore, these typical industrial sectors, such as other electronic equipment industry, textile wearing and apparel industry and articles for culture, education and sport activity industry, experienced the decreasing trends for their net exports. In addition, industrial sectors have the diversified feedbacks from different environmental and resources indicators, indicating that more indicators from trade should be explored specifically. 


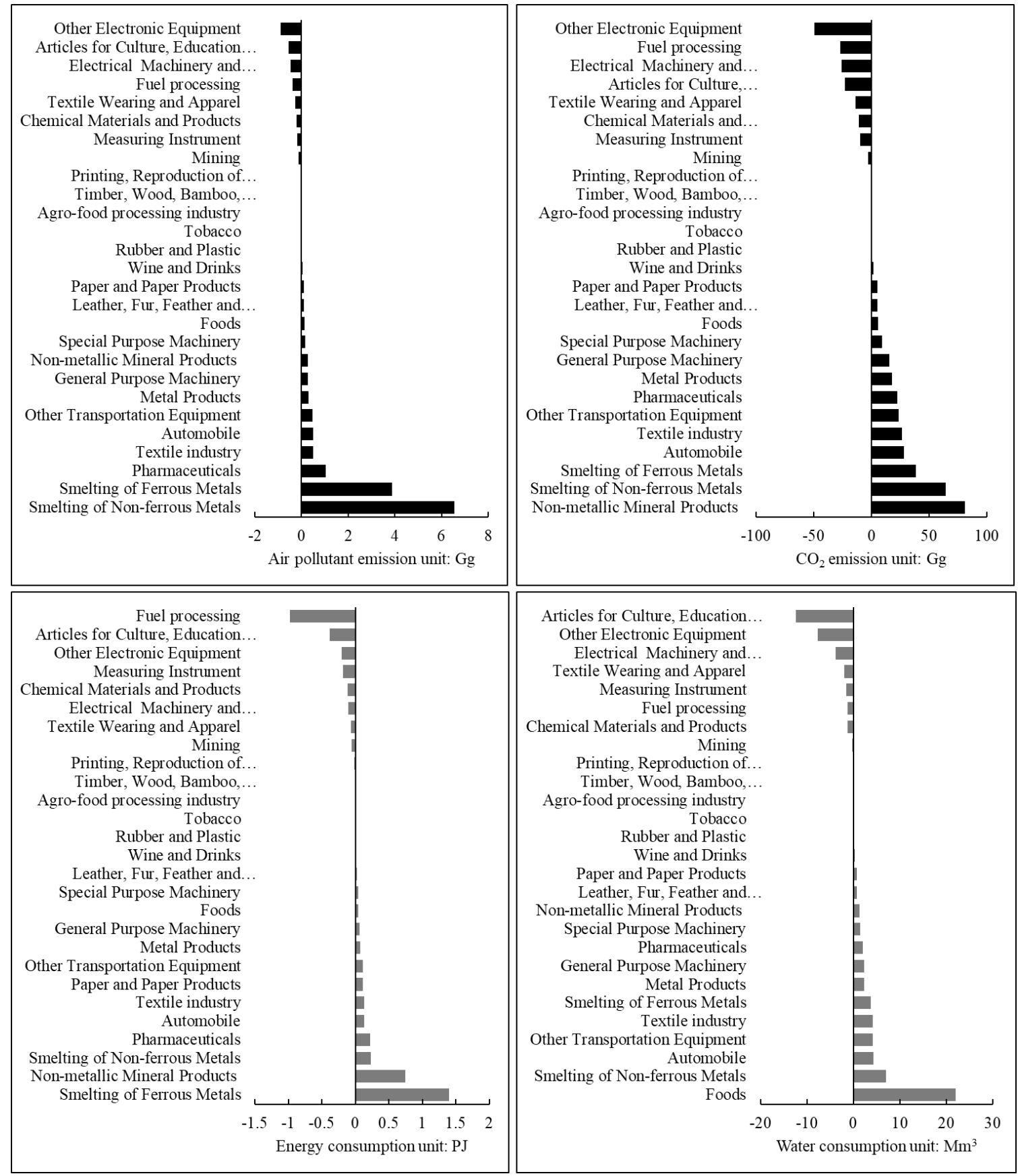

Figure 2 Environmental and resource impacts of China's net export

We further investigate specific countries illustrated in Figure 3. Overall, compared with non-BRI countries, China's net exports have increased by $66 \%$ to the BRI countries. The fastest growing countries include Vietnam, Philippines, Iran, Thailand and Saudi Arabia, and their net exports annually increased by 18.7, 10.3, 8.1, 7.9 and 7.4 billion USD, respectively. In addition, China's net imports from countries such as Palestine, Iraq, Turkmenistan, India and Turkey also increased. 
Concerning air pollutants emission, 49 out of 58 BRI countries benefited from the trade changes due to the BRI policy. Vietnam, Indonesia, Saudi Arabia, India and Malaysia are major beneficiaries: China's net export to these countries increased significantly in those industrial sectors with heavy air pollution, with 147.1, 83.2, 69.8, 63.6 and 57.9 Gg more air pollutant emission in China, compared to the BAU scenario. Furthermore, the top five industrial sectors where China's net exports increased in these five countries include smelting and pressing of ferrous metals industry, smelting and pressing of non-ferrous metals industry, processing of petroleum, coking, and processing of nuclear fuel industry, smelting and pressing of ferrous metals industry and smelting and pressing of non-ferrous metals industry, respectively. These industrial sectors are clearly air pollution intensive according to the classifications by the Ministry of Ecology and Environment of the People's Republic of China ${ }^{6}$.

As for $\mathrm{CO}_{2}$, the increased emissions in China are mainly due to China's net export growth to a few BRI countries: Vietnam, Saudi Arabia, Iran, Singapore and Philippines. The main industrial sectors that are responsible for such increases include manufacture of non-metallic mineral products industry for Vietnam and Philippines, and processing of petroleum, coking, and processing of nuclear fuel industry for Saudi Arabia, Iran and Singapore. These countries account for $60 \%$ of the net export growth from China to all the BRI countries.

With regard to energy, 23 countries increased their energy consumption due to trade pattern changes after the BRI implementation, particularly in Saudi Arabia (by 150.2 PJ), Kazakhstan (by 82.7 PJ), Singapore (by 73.1 PJ), Vietnam (by 59.3 PJ) and Iran (by 54.6 PJ). In addition, apart from Vietnam, industrial sectors that are responsible for China's increased energy consumption include processing of petroleum, coking, and processing of nuclear fuel industry.

As for water consumption, $72 \%$ of BRI countries benefited from trade after the BRI, especially in Vietnam, the Philippines, Malaysia, Iran and Saudi Arabia. The industrial sectors responsible for China's increased water consumption include

\footnotetext{
${ }^{6}$ http://www.zhb.gov.cn/gkml/hbb/bgth/200910/t20091022_174891.htm.
} 
manufacture of textile industry for Vietnam, processing of food from agricultural products industry for Philippines and Malaysia, and processing of petroleum, coking, and processing of nuclear fuel industry for Iran and Saudi Arabia.

\section{Discussions and policy perspectives}

It is clear that China's net export growth to the BRI countries, compared to the BAU scenario, has concentrated in pollution intensive and resource consuming industrial sectors, and therefore aggravates China's domestic environmental and resource burden. More specifically, research results show that because of the trade changes after the BRI, the air pollutant emission, $\mathrm{CO}_{2}$ emission, energy consumption and water consumption increased by $11.3 \mathrm{Gg}, 184 \mathrm{Gg}, 1.3 \mathrm{PJ}$ and $27 \mathrm{Mm}^{3}$ respectively. Thus, it is impossible that the BRI would start a new round of pollution shifting. In contrast, our findings about increasing domestic environmental pressure provide valuable policy insights to those decision-makers in China, in which the sustainable concerns should be carefully addressed and integrated into the blueprints for future BRI.

From economic growth point of view, every country wants to be more involved in international trade (Bringezu et al., 2004). China's economy experienced a more than sevenfold increase between 2000 and 2014 according to world bank database, while its energy consumption tripled over the same period (CHBP, 2015). China paid a higher environmental cost to obtain per unit of value-added through exports than its trade partners (Duan and Jiang, 2017), the virtual $\mathrm{CO}_{2}$ embodied in China's net exports accounted for over $30 \%$ of its total national emission, while the virtual $\mathrm{SO}_{2}$ accounted for approximately $25 \%$, and the virtual COD accounted for over $20 \%$ (Tao, 2011). The unbalance between trade development and environmental issues also imposed an “ecological imbalance” on China’s provinces (Tian et al., 2017), in doing so, regional disparity will aggravate. Being the world factory for more than three decades, China has already suffered a lot from all kinds of issues related with pollution and resource depletion (Tian et al., 2018). According to the official documents ${ }^{7}$, the main achievements from free trade zone construction, investment, infrastructure

\footnotetext{
${ }^{7}$ https://eng.yidaiyilu.gov.cn/
} 
improvement and financing aspects since 2013 accelerated the development of trade between China and countries along BRI. Based on our study, if those trade pattern and the GDP growth are pursued as expected, the corresponding resource and environmental impacts will become more severe, especially in China. Under such a circumstance, China should work with its trade partners to assess those impacts and their regional distribution so that policies for abatements can be prepared, such as technology innovation and circular economy. It is also critical that different provinces would play different roles in China's BRI trade. Consequently, it is critical to coordinate between regional development and regional cooperation.

Our country-specific analysis shows that China's net export growth occurred mainly in ASEAN (Association of Southeast Asian Nations) countries such as Vietnam, Thailand, Malaysia, Singapore and Philippines and OPEC (Organization of the Petroleum Exporting Countries) countries such as Saudi Arabia and Iran. Compared to other countries along the BRI, countries from ASEAN and OPEC have long term trade relationships with China, and their trade volumes can be easily influenced by the BRI policy. Similarly, countries from eastern EU would also significantly increase their trade volumes with China in the future due to their infrastructure needs. But it would be essential for both China and these countries to overcome both cultural and legal barriers. In order to decrease environmental and resources impacts of BRI countries, the results from this study suggest the establishment of supply chain international standards across different countries, combined with learning platforms for main stakeholders, including government, business and non-governmental organizations. Assuming that developed countries have more advanced environmental technologies and management capacities, all the BRI countries should seek to learn from these developed countries through technology transfer and capacity-building efforts. Furthermore, since the BRI stretches into South and East Europe, several member states of the EU may be involved in this initiative. Thus, an environmental partnership with the EU extending the MoU on a circular economy signed in 2018 towards the entire BRI would be beneficial; involving the European Environment Agency (EEA) and the European Bank for Reconstruction and Development (EBRD). 
In terms of key areas, research results from this study suggest a focus on energy and metals, especially if energy transition toward low carbon societies will become a goal of the BRI in line with the Paris Agreement on climate change. It is important to note that energy issues can and should be connected with metals and construction sectors in general, bearing in mind the resource nexus approach (Bleischwitz, et al., 2018) with life-cycle wide assessments of critical interlinkages and systemic ecoinnovations including an increased share of secondary materials and their energy use coming from renewable energies. In addition, water management and the nexus with food and energy should become another area of future actions.

In line with recent findings considerate is important to keep in mind that environmental and resource impacts of trade is not a zero-sum game (Fischer-Kowalski et al., 2015). Well managed via standards, other forms of internalizing negative externalities and ambitious goals, trade can result in more resource-efficient production, better pollution control activities, and creating markets for eco-innovation. Under such a circumstance, trade expansion will result in more environmental and resource gains on China and its partners. In order to achieve this, environmental and resource perspectives must be carefully studied and integrated into future planning. The construction of a "Green BRI", through a forum associated with the BRI, is one suggestion so that various countries can share their green technologies and experiences. In addition, more attentions should be paid to sustainable supply chain cooperation between different countries. Each country along BRI has relevant resource endowment advantages as some are rich in fuels (such as OPEC countries and Kazakhstan), minerals (such as Turkey and Mongolia), cheap labors (such as Vietnam and Thailand) and open international markets (Singapore and Malaysia). The establishment of the Astana International Financial Centre (AIFC) could facilitate such investment opportunities along with the Asia Infrastructure Investment Bank (located in Beijing and mainly serving the BRI initiative). However, all this can only yield advantages over time, if principles on a sustainable supply from the Natural Resource Charter, Integrated Water Management ('Dublin Principles') and OECD, due diligence are aligned with broader goals of low carbon economies and a circular economy (Geng et al., 2019). 


\section{Conclusions and outlook}

China's BRI initiative has become a widely accepted international project aiming to improve the infrastructure along the BRI countries. Such a large initiative has striking environmental and resource impacts to the participating countries. This study evaluates the impacts of the Belt and Road Initiative on pollution and resource consumption from the angle of international trade, with a detailed analysis at the industrial sector level. Applying the DID method and using a unique data set helps reveal specific and comprehensive impacts and their spatial and sectorial dimension. Our main finding is that the BRI has aggravated China's environmental challenges because it caused a net export increase from China to the BRI countries, particularly in those industrial sectors that are pollution- and resource intensive, such as smelting of ferrous and non-ferrous metals industries, textile industry, machinery industry and oil-efining industry.

This study can only present what happened and assumes such trends will continue in the future. Consequently, future research should try to adopt a more dynamic view through scenarios development and modelling. With the expansion of BRI and more investment, the continuous growth may lead to detrimental environmental effects and potential knock-on effects. Nevetheless, better regional integration may promote innovations of eco-products and resource-efficient production, which would mitigate both environmental and resource concerns. Practices, such as developing eco-industrial parks (Geng et al., 2013), encouraging renewable investment and greening supply chains, should be explored and built in future scenarios on the BRI. The sustainable cooperation along the BRI should be planned in-depth such as the novel partnerships between China and its trade partners, driven by markets for secondary materials and eco-innovation in general, and address resource interlinkages across water-energyfood- materials.

Limitations exist in this study. Due to the limited available data, only few variables were run in the DID regression. More variables should be developed at the economic, environmental, resources and social levels. Furthermore, systems modelling should be conducted. As we could only assess the manufacturing industries rather than all 
primary and tertiary industries, future research could address the entire life-cycle including extraction and structural shifts towards service. In addition, more spatially explicit analysis is expected to evaluate the impact of BRI at provincial level so that regional strategies can be raised. Finally, the specific impacts of environmental and ecosystem services at the product level should be evaluated in the future if relevant data are available.

\section{Acknowledgments:}

This study is supported by the Natural Science Foundation of China (71704104, 71774100, 71690241, 71810107001), the Fundamental Research Funds for the China postdoctoral Science Foundation, the Shanghai Municipal Government (17XD1401800), and the big data project funded by Shanghai Jiao Tong University (SJTU-2019UGBD-03). Tian Xu values a visiting scholarship at University College London (UCL). The authors are grateful for the comments from the anonymous reviewers of this paper.

\section{Reference}

Abadie, A., 2005. Semiparametric difference-in-differences estimators. The Review of Economic Studies 72, 1-19.

Bleischwitz, R., Spataru, C., VanDeveer, S. D., Obersteiner, M., van der Voet, E., Johnson, C., ... van Vuuren, D. P., 2018. Resource nexus perspectives towards the United Nations Sustainable Development Goals. Nature Sustainability 1, 737-743.

Bringezu, S., Schütz, H., Steger, S., Baudisch, J., 2004. International comparison of resource use and its relation to economic growth : The development of total material requirement, direct material inputs and hidden flows and the structure of TMR. Ecological Economics 51, 97-124.

Bruckner, M., Giljum, S., Lutz, C., Wiebe, K. S., 2012. Materials embodied in international trade-Global material extraction and consumption between 1995 and 2005. Global Environmental Change $22,568-576$.

Cai, X., Che, X., Zhu, B., Zhao, J., Xie, R., 2018. Will developing countries become pollution havens for developed countries? An empirical investigation in the Belt and Road. Journal of Cleaner Production 198, 624-632.

CCSY., 2008-2016. China Customs Statistics Yearbook: General Administration of Customs of the People's Republic of China. Chinese Customs Press, Beijing (in Chinese).

CHBP, 2015. Chatham House analysis of BP, Statistical Review of World Energy 2015, June, http://www.bp.com/en/global/corporate/.

Chen, Y. J., 2018. Economic handbook of the One Belt and One Road Initiative. Economic Science Press, 
Beijing, China.

Dalin, C., Konar, M., Hanasaki, N., Rinaldo, A., Rodrigueziturbe, I., 2012. Evolution of the global virtual water trade network. Proceedings of the National Academy of Sciences of the United States of America 109, 5989-5994.

Donald, S. G., Lang, K., 2007. Inference with difference-in-differences and other panel data. The review of Economics and Statistics 89, 221-233.

Du, J., Zhang, Y., 2018. Does One Belt One Road Strategy Promote Chinese Overseas Direct Investment? China Economic Review 47, 189-205.

Duan, F., Ji, Q., Liu, B. Y., Fan, Y., 2018. Energy investment risk assessment for nations along China's Belt \& Road initiative. Journal of Cleaner Production 170, 535-547.

Duan, Y., Jiang, X., 2017. Temporal Change of China's Pollution Terms of Trade and its Determinants. Ecological Economics 132, 31-44.

Fan, Z., 2018. China's belt and road initiative: A preliminary quantitative assessment. Journal of Asian Economics 55, 84-92.

Fischer-Kowalski, M. et al., 2015. In Report of the International Resource Panel. With Contributions From: Paul Ekins, Julian Fulton, Thomas Kastner, Karin Hosking, Heinz Schandl, Jim West, and Thomas O. Wiedmann, United Nations Environment Programme Paris.

Geng, Y., Sarkis, J., Bleischwitz, R., 2019. Globalize the circular economy. Nature 565, 153-155.

Geng, Y., Sarkis, J., Ulgiati, S., Zhang, P., 2013. Measuring China’s circular economy. Science 339, 15261527.

Grossman, G. M., Krueger, A. B., 1994. Economic Growth and the Environment. Quarterly Journal of Economics 110, 353-377.

Hu, R., Liu, R., Hu, N., 2017. China's Belt and Road Initiative from a global health perspective. Lancet Global Health 5, 752 .

Jian, W et al., 2015. The impact of a pilot reform on the diagnosis-related-groups payment system in China: a difference-in-difference study. The Lancet 386, 26.

Li, J., Shi, Y., Cao, G., 2018. Topology structure based on detrended cross-correlation coefficient of exchange rate network of the belt and road countries. Physica A Statistical Mechanics \& Its Applications 509, 1140-1151.

Lin, L., Moon, J. J., Yin, H., 2014. Does International Economic Integration Lead to a Cleaner Production in China? Production \& Operations Management 23, 525-536.

Liu, C., Liu, Q., Li, J., Li, Y., Wang, A., 2018. China's Belt and Road Initiative in Support of the Resourcing Future Generations Program. Natural Resources Research 27, 257-274.

Liu, Y., Hao, Y., 2018. The dynamic links between $\mathrm{CO}_{2}$ emissions, energy consumption and economic development in the countries along "the Belt and Road". Science of the Total Environment 645, 674-683.

Peters, G. P., Minx, J. C., Weber, C. L., Edenhofer, O., 2011. Growth in emission transfers via international trade from 1990 to 2008. Proceedings of the National Academy of Sciences of the United States of America 108, 8903-8908.

Shuai, J., Chen, C. F., Cheng, J., Leng, Z., Wang, Z., 2018. Are China's solar PV products competitive in the context of the Belt and Road Initiative? Energy Policy 120, 559-568.

Slaughter, M. J., 1998. International trade and per capita income convergence. American Economic Review 194-199.

Tao, H. U., 2011. Post-ante EIA on China's 10 Years WTO Accession. Environment \& Sustainable 
Development 3, 21-22.

Tian, X., Geng, Y., Sarkis, J., Zhong, S., 2018. Trends and features of embodied flows associated with international trade based on bibliometric analysis. Resources Conservation \& Recycling 131, 148-157.

Tian, X., Geng, Y., Viglia, S., Bleischwitz, R., Buonocore, E., Ulgiati, S., 2017. Regional disparities in the Chinese economy. An emergy evaluation of provincial international trade. Resources Conservation \& Recycling 126, 1-11.

Zhang, N., Liu, Z., Zheng, X., Xue, J., 2017. Carbon footprint of China's belt and road. Science 357, 1107.

Zhang, Y., Zhang, J., Tian, Q., Liu, Z., Zhang, H., 2018. Virtual water trade of agricultural products: A new perspective to explore the Belt and Road. Science of the Total Environment 622-623, 988996. 


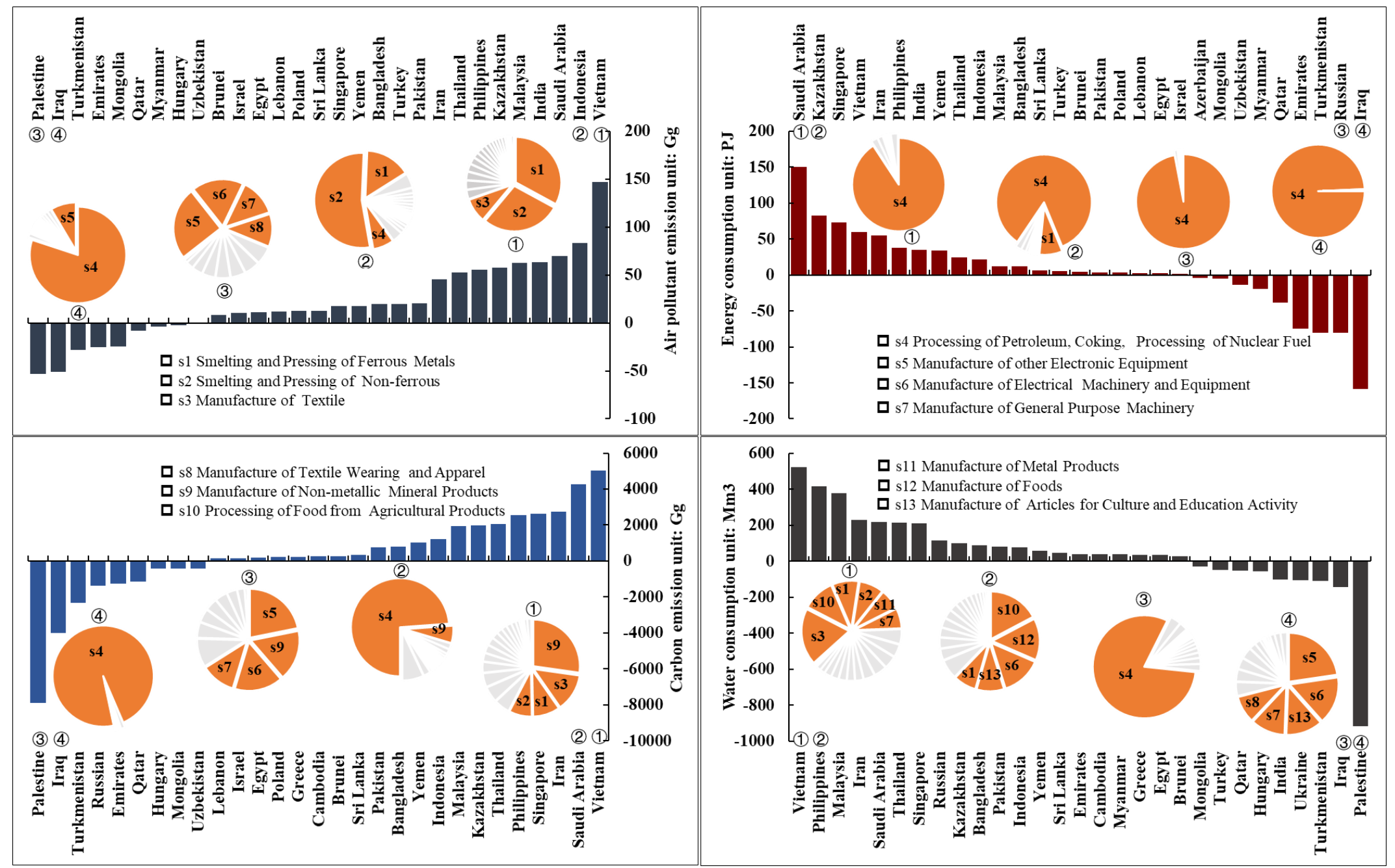

Figure 3 The environmental and resources impacts from BRI 
